\title{
Campaigning for sustainable food: Sustainably Certified Consumer Communities
}

Roberta Discetti, University of Portsmouth

\begin{abstract}
Purpose - The purpose of this paper is to investigate the relationship between consumer movements and sustainability certification bodies in the development of food-related consumer campaigns.

Design/methodology/approach - This paper adopts a longitudinal approach to the study of an empirical case, the Fairtrade Towns movement in the UK. It combines netnographic analysis on the Fairtrade Towns online forum with interviews with members of the community and of the certification body coordinating the movement.

Findings - I conceptualise Sustainably Certified Consumer Communities (SCCC) as a distinct sub-group of consumer movements whose identity coalesces around a sustainable certification and that mobilises supporters with the purpose of promoting social change through the marketplace. The longitudinal approach allows the identification of definitional elements, main practices and unresolved tensions of this concept.

Originality - Research addressing the social movement dimension of contemporary food-related sustainability certification is limited. The present study advances consumer research through the conceptualisation of SCCC and contributes to a new understanding of the political roles market-oriented certification bodies can play in consumer activism. From a managerial perspective, it provides valuable insights to practitioners interested in fostering community engagement.
\end{abstract}

Key words: Consumer movements; sustainable certifications; sustainable labels; voluntary sustainability standards; sustainable community movement organisations; Fairtrade Towns; netnography; consumer activism.

\section{Introduction}

As consumerist culture is increasingly challenged in the light of climate emergencies, grassroots consumer movements are key actors in the global struggle for social justice (Micheletti and Stolle, 2008). Historically, examples of consumer movements can be traced back to the late 1800 s, but they constitute a key feature of the modern consumer society (Hilton, 
2009). A widely cited definition of consumer movements sees them as 'particular kinds of social movements that attempt to transform various elements of the social order surrounding consumption and marketing' (Kozinets and Handelman, 2004, p. 691). Contemporary examples of food-related consumer movements include community-supported agriculture (Thompson and Conskuner-Balli, 2007), solidarity consumer groups (Signori and Forno, 2019), or groups fighting food waste (Gollnhofer et al., 2019). The study of these movements is timely and particularly significant as food and agriculture systems are among the main prerequisites for sustainability (Sage, 2015).

The purpose of this paper is to investigate the relationship between consumer movements and certification bodies in the development of food-related consumer campaigns. Sustainability certification is a growing phenomenon, especially in the agro-food sector (Tröster and Hiete, 2018). Here I use the broad term of certification bodies to refer to organisations managing voluntary ethical standards, also defined as transnational private regulation (King and Pearce, 2010) and voluntary standards initiatives (Potts et al., 2014). Bennett (2017) defines them as "regulations created by non-state actors to improve the social and/or environmental impacts of multinational business, international trade, and/or global production networks" (p. 53).

Recent theoretical developments have de-emphasised the role of organisations in contemporary consumer movements. Scholars have portrayed consumer movements as decentralised, leaderless, and digitally enabled, privileging individual contributions that make up collective action (Wejio et al., 2018; Gollnhofer et al., 2019). How can we couple these important features of contemporary food-related consumer movements with a renewed focus around organisations? Historical approaches have analysed the role of organisations in consumer movements (Hilton, 2009; Anderson, 2015; 2018). However, work addressing the social movement dimension of contemporary food-related certification bodies is limited. Here I propose a dynamic and relational view of consumer movements and organisations that tells not only the story of how they relate to each other - their internal tensions, their negotiated understandings, their collective strategies - but also of what they become in the process.

The main research questions of this study are: in a landscape characterised by digitally enabled phenomena, what is the coordination role that certification bodies play in consumer movements? How does the relationship between campaigner groups and certification bodies evolve as movements institutionalise? What are the wider consequences for our understanding of consumer movements' identity and, ultimately, likelihood of success? In order to address these questions, I investigate the empirical case of the "Fairtrade Towns" movement. Launched in the UK in 2001, the movement promotes the consumption of Fairtrade products in local communities, through the engagement of local authorities, educational actors, faith groups and local businesses. This case was selected for three reasons. First, it proved to be highly successful in raising awareness of Fairtrade, both at individual and at institutional level (Discetti et al., 2019). Second, the UK is the country with the highest number of Fairtrade Towns globally, with more than 400 certified (IFTT, n.d.). Third, the movement is gaining international significance. In the last two decades, it evolved into a global movement, with more than 2000 Fairtrade towns globally, several editions of the annual global conference "International Fair Trade Towns" and an international steering committee (IFTT, n.d.). In 2018, 
the European Commission acknowledged the importance of this movement, organising a European "EU Cities for Fair and Ethical Trade Award" (European Commission, n.d.).

This paper's contribution is twofold. Empirically, this is the first study to use a netnographic approach to provide a longitudinal perspective of the Fairtrade Towns movement, using a rich dataset not previously used by academic research. Since Yahoo's decision to remove online groups content in 2019, this netnography represents an important historical record that could have been lost otherwise. Theoretically, it advances scholarship on consumer movements through the conceptualisation of Sustainably Certified Consumer Communities (SCCC). This concept identifies a specific sub-group of consumer movements and contributes to a new understanding of the political roles certification bodies can play in consumer activism.

The paper is structured as follows. First, I review key literature on consumer movements and present the empirical case of Fairtrade Towns. Second, I describe the key netnographic methodological steps. Third, I outline the SCCC framework and present an analysis of the empirical case based on SCCC analytical dimensions. Next, results are discussed in relationship to the wider literature on consumer movements and mobilisation. Lastly, practical implications and recommendations for future research are developed.

\section{Mobilising consumer participation}

One of the core questions addressed by scholarship on consumer movements $(\mathrm{CM})$ is how they mobilise participation to bring about change in the market. While research addressing this overarching question traverses sectorial boundaries, e.g. fashion (Scaraboto and Fisher, 2013; Närvänen et al., 2019) and tourism (Lee et al., 2018) here I outline recent theoretical development of food-related movements.

The comprehensive framework in which food-related CM are often placed is that of alternative food networks (AFN), namely collective initiatives associated by sustainability, cooperation, and a critique of conventional food networks (De Bernardi et al., 2020). These include several practices, such as community-supported agriculture, solidarity consumer groups and fair trade networks, which are presented below.

Grappling with the question of how CM mobilise participation, Thompson and Coskuner-Balli (2007) study community-supported agriculture (CSA) as an example of countervailing movement resisting the corporate co-optation of countercultures. They show how CSA mobilises supporters through ideals of connectedness, cooperation and communal consumption practices. Recent literature on Brazilian (Matzembacher and Meira, 2019) and US based CSA initiatives (Witzling et al., 2020) reinforces the importance of community bonds in supporter mobilization and retention. Another well-studied AFN phenomenon is that of solidarity consumer groups (Signori and Forno, 2019; Dal Gobbo and Forno, 2020), i.e. the collective purchase of food through direct relationships with local producers, motivated by political and environmental concerns. This recent work highlights how consumers groups privilege direct interaction and reject higher-level organisation, characterising them as fundamentally 
horizontal phenomena (ibid.). Hoelscher and Chatzidakis (2020) further stress notions of direct interactions and craving for physical connections in their study of ethical consumption communities. Defined as groups of individuals with a common interest for just modes of consumption, these collectives engage in activities such as community gardens, vegan cooking workshops and alternative healing practices, intertwining physical and digital participation (ibid.).

Wejio et al. (2018) offer a further perspective on CM and mobilisation, through the analysis of the case of Restaurant day, a movement responding to the constraining food culture regulations in Nordic markets through pop-up restaurants and public performances. They identify creativity as an immediate participatory mechanism, which recruits participants through playfulness and inspiration. Recognising creativity as a mechanism of distributed participation, they emphasise individual contributions to collective action. An additional theoretical perspective is that of Gollnhofer et al. (2019). In their paper about the German movement to fight food waste, they explore the evolution of object pathways from the controversial practice of dumpster diving to the emergence of projects of reduction of food waste in collaboration with retailers. In linking dumpster divers' desire for alternative outcomes related to food waste with the emergence of practice innovation, their attention is again on individual agency and horizontal networks.

This overview shows how the main recent theoretical developments in the study of CM emphasise individual perspectives and distribute participation. Broader social movement literature mirrors this trend, portraying social movements as largely leaderless (Morris and Staggenbord, 2004) and de-emphasising the role of centralised organising (Earl and Kimport, 2011; Castells 2015). A welcome exception is the work of Forno and Graziano (2014; 2020). They elaborate the notion of Sustainable Community Movement Organisation (SCMO) as "social movement organisations that have the peculiarity of mobilising citizens primarily via their purchasing power and for which their main 'battlefield' is represented by the market" (Forno and Graziano, 2014, p. 142). They highlight how SCMO mobilise supporters not via contentious activities but by pursuing alternative forms of consumption based on knowledge exchange and trust. While their study captures key elements of the relationship between organisations and consumer communities, there is scope to elaborate on the relationship campaigners establish with a specific form of organisation, namely certification bodies concerned with food sustainability.

This paper builds on these theoretical efforts to understand how CM mobilise participation and seek to change the food marketplace. However, it complements the focus on horizontal participation with a reconsideration of the role of organisations - particularly certification bodies - through the analysis of the empirical case of Fairtrade Towns. I now move to introduce the empirical context and present key literature on the topic. 


\section{Introducing Fairtrade Towns}

One of the most successful initiatives linking fair trade consumption and collective action is the Fairtrade Towns (FTT) movement, described as an antidote to depoliticised ethical consumption (Low and Davenport, 2007). The initiative started in 2001 in England, when local volunteers guided by Bruce Crowther, an Oxfam campaigner, set up a group to promote Fairtrade. Working on a similarity of intents between the "buycott" of Fairtrade products and the "boycott" of slave-produced sugar within the movement to abolish British slave trade, the group succeeded in gaining the support of the council, who voted to self-declare a 'Fairtrade Town' (Lamb, 2008).

Following internal consultations, the organisation that licenses the use of the Fairtrade label in the UK - the Fairtrade Foundation - envisaged this movement as an opportunity to expand the awareness and sales of Fairtrade certified products; it then produced a set of criteria to scale up the initiative and to enable more cities to follow. The 'five goals' are (Fairtrade Foundation, 2002):

1) Local council passes a resolution supporting Fairtrade.

2) A range of Fairtrade products (i.e. coffee, cocoa, rice) is available in the area's retail and catering outlets.

3) Local workplaces and community organisations (i.e. places of worship, schools, universities, and colleges) support Fairtrade.

4) Media coverage and events raise awareness of Fairtrade across the community.

5) A local Fairtrade steering group is convened to ensure the campaign continues to develop.

The FTT movement has sparked scholarly interest across several disciplines. First, marketing scholars have defined FTT as the idea of expanding the Fairtrade label from products to places (Alexander and Nicholls, 2006; Samuel et al. 2018). Second, geography scholarship has analysed this movement with a broader focus around the concept of place. Malpass et al., (2007) and Low and Davenport (2007) have highlighted how in FTT place becomes a mobilizing device for collective action through the mediation of local authorities. The potential of political and institutional actors in driving this movement is even stronger in the emergent FTT campaign in Latin America and the Caribbean (Coscione, 2015; Barone and Frederico, 2015).

An additional theoretical approach draws from social movement literature. Shawki (2015) investigates how the Chicago FTT campaign displays generative practices, namely novel forms of organizing that focus on civic engagement rather than oppositional politics. Within the British context, exploratory work by Peattie and Samuel (2018) revealed some important aspects of the relationship between FTT groups and the Fairtrade Foundation, framing it in terms of networks of ethical activism. Nonetheless, their study focuses mainly on activists' perspectives, and they invite future research to explore further the Foundation's role. This paper 
responds to their call, employing a longitudinal approach to produce a detailed analysis of the evolution of the relationship between the Foundation and campaigners.

\section{Methodology}

This research combines netnographic methods with semi-structured interviews. The netnographic approach adopted corresponds to what Kozinets $(2010 ; 2020)$ outlines as purely observational and unobtrusive netnography, in which the main data collected are archival and investigative. While archival data provides a sufficient basis to explore the online interactions on a longitudinal basis, Kozinets suggests to "blend" netnography with other approaches for the study of communities which extends beyond the digital world (ibid.). Therefore, netnographic data has been complemented with interviews.

\section{Data collection}

Netnography encompasses three types of data: archival (pre-existing computer-mediated communications), elicited (co-created by the researcher and members of the community) and field notes (Kozinets, 2010). These three types have been collected as follows.

Archival data was gathered from the Fairtrade Towns Yahoo Group, the key online group for the Fairtrade Towns movement, launched in 2001 and active until 2017. This group was chosen as it constitutes a long-lasting source of collective memory of the FTT movement: the 450 participants represented more than 100 communities in the UK and included members of fair trade companies, local authorities, NGOs and universities, as well as member of staff of the Fairtrade Foundation. Data was collected in an observational and unobtrusive fashion.

Elicited data was drawn from semi-structured interviews. First, a long exploratory face-to-face interview with the Fairtrade Towns campaign manager was realised. The content of the interview revolved around three main themes: evolution of the campaign; synergies and tensions between organisational and campaigners' narratives; impact of the campaign on organisational strategies. Following this, eight phone interviews with members of the National Campaigner Committee (NCC) were arranged. The NCC is a group of 12 elected Fairtrade campaigners who each represent a region of the UK. It was founded in 2010 with the purpose of enhancing dialogue between FTT communities and the Fairtrade Foundation. Interviews revolved around two main themes: local groups' narratives of change; interconnections between local and organisational narratives, networks and strategies.

Lastly, immersive field notes were produced throughout all stages of data collection. The two main immersive operations (Kozinets, 2020) were: recording, i.e. chronicling the process of search and investigation; and reflecting, namely first-person ethnographic reflections about encountering a specific social environment. Field notes guided and informed the process of analysis and interpretation. 


\section{Data analysis}

Netnographic analysis involves a 'thick' understanding that combines analytic coding with hermeneutic interpretation (Kozinets, 2020). The three main analytic operations performed were collating, coding, and combining (ibid.). First, collating constitutes a form of data cleansing achieved through filtering, formatting and filing the data (ibid.). Following these protocols, all redundancies and errors of download were eliminated, and data was converted in word format, including transcripts of interviews. This macro dataset was then grouped into smaller datasets following the progressive identification of themes, a reclassifying work suggested by Kozinets (2010) for the organisation of large bodies of archival data. Following this, descriptive coding was carried out on the whole dataset, to allow researcher's familiarisation with data and further filing. Subsequently, analytic coding was performed on smaller datasets. Lastly, combining related codes into pattern codes, namely a higher-order codes, allowed the construction of conceptual material and structures (Kozinets, 2020).

Analytic procedures have been coupled with hermeneutic interpretation, which early consumer research established as fruitful paradigm (Arnould and Fischer, 1994) and later became a privileged approach to netnographic analysis (Kozinets et al. 2014). Hermeneutics is grounded in the idea that consumers' discourses articulate systems of cultural meanings; therefore, the focus of hermeneutics is the underlying meaning systems contained in participants' views rather than their strictly subjective viewpoints (Thompson and Coskuner-Balli, 2007). The two main interpretive processes used for this study were theming, i.e. identification of higher order themes stemming from codes, and translating, i.e. moving from an emic to an etic understanding of the phenomenon (Kozinets, 2020). The interpretation therefore followed an iterative, recursive process, circling between data and notes. Table 1 offers a summary of data collection and analysis steps.

\section{Table I. Blended netnography methodological steps}

\begin{tabular}{lcl}
\hline Data collected & Analysis and interpretation protocols \\
\hline Archival data & $\circ$ & All posts were downloaded with PG Offline software \\
7508 Posts from the online group & $\circ$ & Collating: filtering, formatting, filing \\
763,175 Total word count & $\circ$ & Coding (descriptive) across the entire dataset \\
& $\circ$ & Coding (analytic) on smaller datasets \\
& $\circ$ & Combining codes into pattern codes \\
\hline Elicited data & $\circ$ & \\
9 semi-structured interviews & $\circ$ & Interviews were recorded and transcribed \\
11 total hours recorded & $\circ$ & Coding (descriptive) across the entire dataset \\
& $\circ$ & Coding (analytic) on smaller datasets \\
& $\circ$ & Combining codes into pattern codes \\
\hline Field notes & & \\
Researcher's reflexive notes & $\circ$ & Immersive notes: recording, reflecting \\
& $\circ$ & Theming: identifying emerging themes from data and notes \\
& $\circ$ & Translating from emic to etic viewpoint, circling between \\
& & pattern codes, themes and reflexive notes
\end{tabular}




\section{Conceptualising Sustainably Certified Consumer Communities}

Diani (2019) notes that scholars refer to "consumer movements" to indicate, in loose terms, multiple sets of actors (individuals, groups, organisations) and practices (i.e. boycott, buycott, private regulations), making the identification of specific forms of collective action challenging. This paper responds to this challenge by conceptualising Sustainably Certified Consumer Communities (SCCC) as a distinct form of collective action, with specific actors and practices. Here I define SCCC as a sub-group of consumer movements whose identity coalesces around a sustainable certification and that mobilises supporters with the purpose of promoting social change through the food marketplace. Key definitional elements of SCCC are: the combination of online/offline networks; the symbolic value assigned to the sustainable certification; the reciprocity of the relationship between certification bodies and activists (see Table II for a summary).

Online/offline networks. Digital media play a key role in enabling ongoing communication between activists and certification bodies, which is at the very centre of SCCC identity. The important role of digital ties matches existing scholarship on food-related consumer movements (Wejio et al., 2018; Gollnhofer et al., 2019). However, SCCC repertoire presents a combination of online/offline tactics, with offline action ranging from promotional stalls and public performances to lobbying businesses and local authorities. The key role the certification plays in both establishing digital networks and coordinating offline actions presents an opportunity to engage with the notion of "managing" consumer communities. The prevailing notion in consumer research is that consumer communities are challenging to manage, epitomised by the concept of "unmanageable" consumer developed by Gabriel and Lang (2006). While acknowledging that the concept of unmanageability seizes the elusive and multifaceted nature of contemporary consumption, the notion of SCCC captures the experience of "managed" consumers. This resonates with the study by Närvänen et al., (2019) showing that managing consumer communities is possible through a combination of framing, activating and mobilising. Similarly, the concept of SCCC entails that certification bodies can succeed in assembling consumer movements' identity, claims, and practices through a combination of online and offline networks.

Symbolic value. In SCCC, the sustainable certification is loaded with symbolic significance, where it reflects a broader political project and embodies multiple intertwined political sensitivities. SCCC associate the promotion of the sustainable certification to the practice of consumer-citizenship, i.e. the expression of rights, responsibilities and resistance through consumption, which constitutes a key marker - albeit limited - of democratic citizenship (Jubas, 2007). Participating in SCCC is also connected to the practice on food citizenship, i.e. the demand of civic rights and expression of international solidarity through food consumption (Sage, 2014). In this sense, SCCC represent a prefigurative style of politics that embeds social and ecological sustainability into the production and reproduction of social life (Dal Gobbo and Forno, 2020). Acting simultaneously on economic, cultural and political level, the notion of SCCC complements the concept of Sustainable Community Movement Organisation 
developed by Forno and Graziano $(2014 ; 2020)$, with focus on labelling organisations in the context of food sustainability.

Reciprocal relationship. In SCCC, campaigners establish and maintain a mutual ongoing exchange with the certification body; the latter actively engages with activists and the relationship influences both actors' strategies and identities. This resonates with points by Forno and Graziano $(2014 ; 2020)$ and by Kurth and Glasbergen's $(2017)$ that trust is a key element in the relationship between organisations and consumer communities. What the concept of SCCC stresses, though, is the mutuality of trust and engagement. From this perspective, the conceptualisation of SCCC has some resonance with the notion of brand communities. Muniz and O'Guinn (2001) defined brand communities as "specialized, nongeographically bound community, based on a structured set of social relationships among admirers of a brand" (p.412). SCCC, though, differ from brand communities for two reasons. First, although SCCC collective action is market-oriented, their commercial scope is instrumental to a wider political project, while brand communities are explicitly commercial. Second, while discourses of citizenship, mobilisation and political action are central to the participation in SCCC, they are not part of the definition of brand communities.

Table II. Conceptualising Sustainably Certified Consumer Communities

\begin{tabular}{|c|c|c|}
\hline Definitional elements & Main practices & Emerging tensions \\
\hline Online/offline networks & $\begin{array}{l}\text { - Horizontal online dialogue among } \\
\text { communities and vertical online dialogue } \\
\text { with certification body } \\
\text { - Combination of online/offline } \\
\text { mobilisation and participation }\end{array}$ & $\begin{array}{l}\text { - The elaboration of a collective identity } \\
\text { enabled through digital ties may collide } \\
\text { with localised consumption community } \\
\text { identities }\end{array}$ \\
\hline Symbolic value & $\begin{array}{l}\text { - Buycott, ethical and political } \\
\text { consumption of certified products } \\
\text { - Awareness raising activities and } \\
\text { educational programmes focused around } \\
\text { the certification label }\end{array}$ & $\begin{array}{l}\text { - The promotion of the certification label } \\
\text { is prioritised above locally relevant } \\
\text { campaign narratives. This enhances } \\
\text { cohesion of national campaigns but } \\
\text { hinders movements' complexity }\end{array}$ \\
\hline Reciprocity of the relationship & $\begin{array}{l}\text { - Campaigners mobilise local } \\
\text { participation in order to promote the } \\
\text { certification label } \\
\text { - The certification body develops a } \\
\text { formalised and routinized award to certify } \\
\text { communities } \\
\text { - Ongoing mutual engagement thorough } \\
\text { conferences, training, national meetings, } \\
\text { co-production of knowledge and shared } \\
\text { emotions }\end{array}$ & $\begin{array}{l}\text { - Professionalization enables the } \\
\text { movement to scale up but routinized } \\
\text { organisational strategies may hinder } \\
\text { campaigners' creativity and emotional } \\
\text { connections }\end{array}$ \\
\hline
\end{tabular}




\section{From consumer crowd to SCCC: the case of Fairtrade Towns}

The following sections offer an examination of the empirical case based on the analytical dimensions identified. The longitudinal approach allows unpacking the processes that substantiated the change of Fairtrade Towns from a spontaneous crowd to an organisationally coordinated consumer movement, displaying (i) online/offline networks; (ii) symbolism; (iii) reciprocity.

\section{Online-offline networks: engaging with e-mobilisation}

Few months after the first town self-declared as a Fairtrade Town in 2001, the Fairtrade Foundation signalled its readiness to support the nascent movement and certify communities with a "Fairtrade award". The Foundation took ownership of the initiative through the elaboration of a range of measurable targets designed to capture the impact of local campaigns. These were implemented through a digitally enabled programme including an application process, online feedback and the awarding of a certificate. While the first Fairtrade Town was self-declared by a grassroots initiative, from 2002 onwards the declaration of Fairtrade Town status became a formal process directed by the labelling organisation through a range of etactics (Earl and Kimport, 2011).

In these first years (2001-02), the Fairtrade Foundation had limited control on the circulation of resources and narratives. Activists showed a form of spontaneous creativity that characterises what Kozinets et al. (2008) call 'crowds': a type of collaborative consumer community that does not present formal leadership. Following the adoption of the initiative, the Fairtrade Foundation started a process of professionalization (Kriesi, 1996) of the movement. In 2003, the Foundation nominated Bruce Crowther, the originator of the grassroots campaign, as the first Fairtrade Town coordinator, working as an organisational link with local groups. Through Crowther's voice, the Foundation's role in shaping the collective identity and narratives of the movement became more central.

This process was enabled and documented in the online exchanges on the FTT Yahoo group. In Crowther's words, the forum represented a "wealth of knowledge" that campaigners both consumed and co-produced:

I have always said that I think it [the forum] is the best resource we provide for Fairtrade Towns. There is nothing stronger than sharing experiences of others who often have either successfully overcome a problem or simply are pondering over the same problem as you. (Bruce Crowther, 2006, Yahoo Group).

Throughout the years, online networks enabled horizontal communication among campaigners and, significantly, vertical coordination with the Fairtrade Foundation. The organisation ensured a strong online presence in answering activists' questions, with several organisational teams (commercial, campaigns, communication) providing guidance. While papers by Peattie 
and Samuel (2018) and Malpass et al., (2007) analysed offline campaign tactics, netnographic data shows how this picture is incomplete without a consideration of online engagement. Through a combination of e-tactics and ongoing online communication, the Fairtrade Foundation ultimately engaged with e-mobilization, a key repertoire of contemporary social movements (Earl and Kimport, 2011).

Symbolism: embedding the Fairtrade Mark

During the emergence phase (Blumer, 1951), the movement relied mostly on institutional entrepreneurs (Scaraboto and Fisher, 2013) i.e. individual campaigners who acquired legitimacy in their communities and ignited participation locally. Narratives and practices were frequently re-articulated and translated into something significant for the local level. Port cities with a past in slave trading such as Liverpool and Bristol were linking Fairtrade to the abolitionist movement as a means to rework the city's identity. Towns with an economy based on tourism were linking Fairtrade to responsible tourism, and cities with highly intercultural societies were coupling Fairtrade with messages of integration and inclusive communities. As the current Campaign Manager puts it:

In the early phase of the movement, [...] the message, the narrative, didn't need to be that defined. At the local level, the flexibility of the narrative was the real strength. [...] It didn't need much discipline, the grassroots nature was the absolute core, the fact that people were hearing about Fairtrade from their neighbours, their priests, their teachers, in their local newspapers and not just in marketing campaigns of big brands. (Campaign Manager, interview, 2018)

Benford (2002) notes how a movement's success is linked to its ability to exert control on individual interpretations and transform them in a coordinated fashion. From this perspective, the horizontal circulation of locally relevant narratives - despite igniting mobilisation represented a threat to organisational coherency. This was exacerbated by the success of the initiative, linked to phenomena of co-optation and dilution of Fairtrade concepts. The Fairtrade Foundation responded to these challenges establishing the promotion of the Fairtrade mark as the central aim of the FTT movement. Through the Yahoo group, the Fairtrade Foundation activated a process of boundary definition (Diani, 2019), legitimising or delegitimising vernacular narratives:

As the person who pioneered the whole initiative, I should at this point mention that I saw the introduction of the FAIRTRADE Mark into the UK in 1994 as an opportunity to move fair trade into the mainstream, which indeed it has done. The Fairtrade Towns initiative was devised as a tool to achieve this through promoting the FAIRTRADE Mark. So Fairtrade Towns are about getting mainstream places such as Starbucks, M\&S or small independent stores that would not normally sell fair trade products to sell products that carry the FAIRTRADE Mark. (Bruce Crowther, 2007, Yahoo Group) 
By framing the overall strategy of the campaign as the promotion of the Fairtrade label in mainstream channels, the Foundation provided the movement with a collective prognostic frame (Benford and Snow, 2000). Through the phases of coalescence and institutionalisation (Blumer, 1951), and increasingly from 2008 onwards, the re-articulation of narratives progressively decreased, with the majority of groups aligning with this central frame. Activists' dialogue in these years is saturated with constructs that highlight the simplicity, recognisability, and clarity of the certification, epitomising the values of the wider movement:

The Fairtrade Mark is THE symbol of fair trade and respect for producers in the developing world. I don't want lots of other symbols or ethical statements or explanations as to why products are ethically ok to buy. (Campaigner, 2007, Yahoo group)

The choice of the promotion of the Fairtrade label as the main focus on the movement proved to be particularly successful, since the awareness of the label reached $92 \%$ of the British population by 2017 (Fairtrade Foundation, 2018). The label evolved into a symbol of the wider political goals of the fair trade movement - supporting producer cooperatives, gender equality, ecological farming - as in a synecdoche in which, pars pro toto, the certification denoted the polysemy of collective action. Nonetheless, the ongoing loss of complexity hindered the movement's ability to embrace emerging inputs from local communities. The shift from spontaneous narratives to a nationally coordinated frame progressively side-lined diverging strategies, with the effect of both consolidating the movement on a national scale and weakening its internal creativity.

\section{Reciprocity: enabling and nurturing connection}

The relationship between the FTT movement and the Foundation has deeply affected both sides. On one hand, the organisation shaped campaigners' collective identity, enabled shared emotions, and institutionalised the movement. On the other, campaigners' creativity and political drive enabled the organisation to broaden its identity beyond a market-oriented certification, to embrace the role of a grassroots-oriented SCMO. I will now analyse the dimension of reciprocity from both perspectives.

Examining the transformation of campaigners groups into coordinated consumer communities, the role of the Foundation in enabling shared emotions is fundamental. Emotions shape the goals of social movements and motivate individuals through fundamental human drives, such as connection, impact and curiosity (Jaspers, 2011). The Fairtrade Foundation played a key role in activating both reciprocal and shared emotions (Goodwin et al., 2000) connected to these deep human goals. The organisation supported shared emotions of outrage and anger towards global injustices of the food marketplace, and stirred up desires of impact. However, while negative emotions are powerful in movements' mobilisation, they can generate feelings of powerlessness (Castells, 2015). The Foundation countered these feelings through the 
activation of reciprocal emotions of friendship, solidarity, and loyalty. These were fostered by conferences, training, and opportunities of dialogue, which built a sense of connection to the wider movement. This matches existing findings on how collective action around the consumption of food activates connectedness and trust (Thompson et al., 2007; Signori and Forno, 2019; Dal Gobbo and Forno, 2020). However, while the diffuse solidarity activated by Sustainable Community Movement Organisations has been defined as mostly rooted in the territory (Forno and Graziano, 2014), this study shows how organisations can foster such emotions also towards distant actors, in this case the people responsible for food production in distant communities. Feelings of connectedness were enhanced through regular exchanges and visits by Fairtrade producers to Fairtrade consumer communities. In this quote, Bruce Crowther meets a member of a Ghanaian cocoa cooperative:

Samuel, our visitor from our Ghanaian twin town New Koforidua left today and before he went we watched the film Gandhi together, a big favourite of mine. [...] Of course we are not Gandhi but I think we can use the same message that he spoke of [...]. As for the slave trade and colonialism, you could imagine how Samuel and I felt as we left the slave trade museum. There were many letters about feeling ashamed so we added the following message on behalf of our Garstang and New Koforidua link: "Do not feel shame but let these past injustices strengthen and motivate you to take positive action today against their legacy." (Bruce Crowther, 2008, Yahoo group)

The emotions connected to the consumption and promotion of Fairtrade products shaped the collective identity of FTT activist as global citizens (Malpass, et al. 2007) and rooted cosmopolitans (Shawki, 2015). From an organisational perspective, the mutual relationship established with campaigners translated into a transformation of the organisational scope. With the launch of the FTT scheme, the Foundation started to review its allocation of resources, creating a "campaign team" focused on coordinating the movement. Significantly, following an iterative form of consultation, in 2010 the organisation established a "National Campaigner Committee", an elected body of campaigners' representatives. This committee advises the organisational board, and has the purpose of fostering dialogue between the grassroots component and organisational decision-making. Reflecting on the engagement with consumer communities, the campaign manager comments:

[the FTT movement] has shifted the focus I think, because if FTT had never happened... I mean you can look at other countries where it didn't happen in that way, and you can see that the national organisations don't have a campaign team, don't have a school programme, don't have universities, churches, and therefore, I think, often they don't have as much sales. They probably don't have as much policy and political advocacy. So I think it has definitely shifted our focus to do more advocacy, because we can see that there are a lot of people supporting this, therefore we have a mandate to speak to governments. (Campaign manager, interview, 2018)

The reciprocal relationship broadened the scope of organisational activities to include political mobilisation and engagement with policy makers on behalf of certified communities. When the 
FTT movement emerged, the Foundation's purpose was establishing a market for Fairtrade products. Throughout the ongoing relationship with the movement, though, the commercial purpose blended with political mobilisation, expanding the identity and aims of the certification body.

\section{Theoretical advancements and future research}

The conceptualisation of SCCC has a number of implications for our understanding of CM and mobilisation. First, it identifies positive symbolism as a key dimension of CM collective identity. Second, it represents a form of community that bridges local alternatives with global brands in the pursuit of more just modes of production/consumption. Last, it provides managers and practitioners with valuable insights on engaging with consumer communities.

\section{Positive symbolism and collective identity}

When theorising the structural components of CM, Kozinets and Handelman (2004) identify three core dimensions: their goal, their identity and their adversary. Defining CM as 'adversaries of consumption', they privileged the contentious dimension of their ideology. This approach was later applied to a multitude of studies, what Moraes et al. (2010) call an anticonsumption literature. The notion of SCCC constitutes an opportunity to expand Kozinets and Handelman's analytical dimensions of CM definition. While "goal" and "identity" remain central in the notion of SCCC, the concept of adversary becomes less prominent. SCCC do not motivate mobilisation with the opposition to a despicable adversary, they rather coalesce around a symbolic referent that embodies the kind of change they aim to achieve. Therefore, I suggest "positive symbolism" as a key element that contributes to understanding CM identity and mobilisation. In emphasising how CM might build their identity around a positive symbolism rather than around contentiousness and oppositionality, this paper expands the scope of literature on CM and collective identity. In doing so, it joins scholars calling to extend scholarship on CM beyond the traditional concepts of resistance and subversion, to include concepts of consumer entrepreneurship (Moraes et al., 2010) collaboration (Laamanen et al., 2015) and creativity (Wejio et al., 2018).

The entanglements of collective identities between consumer communities and private regulations is likely to gain even more prominence in the future, given the proliferation of certification schemes and the increasing demand for sustainable food. While the longitudinal approach unpacks the main analytical dimensions of SCCC, this paper has limitations in that empirical evidence is delimited to one specific movement within one national context. It would be valuable to reflect on how the dynamics presented here transfer to other relevant contexts, e.g. religious certifications (Kurth and Glasbergen, 2017) or leisure communities (Närvänen et al., 2019). 
In order to explore the wider consequences of the SCCC concept, work by Thompson and Coskuner-Balli (2007) is particularly useful. They conceptualise two poles of debate on the role of consumption communities within globalisation. On one side, the notion of brand communities (Muniz and O' Guinn, 2001) assigns to mainstream businesses the role of beacons of socially responsible capitalism. On the other, opponents of neoliberal globalisation remain wary of global brands and rather support local non-corporate alternatives (Kozinets and Handelman, 2004; Moraes et al., 2010). The notion of SCCC mitigates this polarization, presenting a novel form of organising that occupies a middle position in this spectrum of consumption communities. While SCCC promote localised consumption and engage in decommodification practices, they also envisage the possibility for brands to act as agents of change through the independent certification and the promotion of transparency. SCCC aim to engage both with radical networks of alternative consumption and with mainstream actors and narratives. In this sense, the certification performs a negotiating role between diverging attitudes; more precisely, the place-based and community-focused certification works as a mediating force between the search for radical local alternatives and the insurgence of global brands as agents of social change.

Importantly, in order to advance our understanding of CM role in a more just globalisation, future research should critically traverse the epistemic divides of consumption/production and North/South. This would translate into an exploration of SCCC in relation to producer communities in the global South. The concept of community is recognised as a privileged space for inclusive economy at the production level (Winkel et al., 2020) and therefore an exploration of the potential of SCCC for local development would be very valuable. Moreover, the boundaries between consumption/production, digital/material and alternative/mainstream are being increasingly challenged both in academic research and in consumption practices (Eden, 2017). In parallel, the rise of ethical consumption in the Global South is challenging existing North-South dichotomies (Gregson and Ferdous, 2015). Further research is therefore needed to reconfigure the assumptions around consumption/production and North/South in scholarship on consumer movements, and a focus on certified communities can help navigate these divides.

\section{Practical and policy implications}

From a managerial perspective, the SCCC framework constitutes a valuable resource for all certification bodies seeking to mobilise consumers. Since consumption communities play a strategic role in contemporary markets, the analytical dimensions presented here can be useful to all managers and practitioners interested in fostering community engagement. It is important that managers and practitioners channel their effort into building mutual and trustful relationships with supporters through online/offline networks, as well as centring supporter 
mobilisation on positive symbolism rather than on contentiousness. This research provides empirical evidence that the adoption of these strategies boosts community engagement, resulting in increased commercial success and political legitimacy. This paper also presents some policy implications. SCCC strive to transform the global food marketplace through multistakeholder partnerships. Policy makers concerned with food sustainability can therefore develop an enabling policy environment that allows SCCC to form and thrive. Particularly, they can cooperate with SCCC on key local policy areas for sustainability: public procurement, local economic development, international cooperation, awareness raising, and multistakeholder engagement (FTAO, 2016). Through these, SCCC can be a fundamental policy tool to achieve localised and decentralised sustainability in the food marketplace.

\section{Conclusions}

Increasing inequalities and climate emergencies are adding new pressures to global food and agriculture systems. The grossly uneven distribution of wealth and the deterioration of environmental resources urgently demand a reconsideration of current forms of production and consumption. Starting from this premise, I investigated two key actors of the contemporary food marketplace, namely consumer movements and private certification bodies. In order to better understand their relationship, I proposed the new construct of Sustainably Certified Consumer Communities. This concept aims to highlight the key role that local consumer communities and sustainability certifications can play in the global struggle for sustainability.

The empirical findings of this study showed how groups campaigning for sustainable food might coalesce around certification bodies for the practice of consumer citizenship and collective action. They also showed how certifications engaging with grassroots campaigns might gain political legitimacy to actively demand policy changes in the way food is produced, traded, distributed and consumed. The synergy between these actors is a promising avenue to achieve more just forms of production and consumption. If we are to seriously address the daunting threats that social and environmental crises are posing to our societies, further investigations on the role consumer communities and private regulations can play are timely and needed.

\section{Disclosure statement}

No potential conflict of interest was reported by the author.

\section{Funding details}

The author received no financial support for the research and/or publication of this article. 


\section{References}

Alexander, A., and Nicholls, A. (2006). "Rediscovering consumer-producer involvement: A network perspective on fair trade marketing". European Journal of Marketing, 40(11/12), pp. 1236-1253.

Anderson, M. (2015). A History of Fair Trade in Contemporary Britain: From Civil Society Campaigns to Corporate Compliance. London: Palgrave Macmillan.

Anderson, M. (2018). "Fair trade and consumer social responsibility: Exploring consumer citizenship as a driver of social and environmental change". Management Decision, 56(3), pp. 634-651.

Arnold, S. J., and Fischer, E. (1994). "Hermeneutics and consumer research". Journal of Consumer Research, 21(1), pp. 55-70.

Barone, M., and Frederico S. (2015). La Ciudad Brasileña Del Comercio Justo: Una Experiencia Pionera En Poços De Caldas. Eutopía. Revista De Desarrollo Económico Territorial, n. ${ }^{\circ}$ 7, 59-73.

Benford, R., (2002). "Controlling narratives and narratives as control within social movements", Davis, J.E. (Ed.s), Stories of Change: Narrative and Social Movements. Albany: State University of New York Press.

Benford, R. D., \& Snow, D. A. (2000). "Framing processes and social movements: An overview and assessment. Annual review of sociology, 26(1), pp. 611-639.

Bennett, E. A. (2017). Who governs socially-oriented voluntary sustainability standards? Not the producers of certified products". World Development, 91, pp. 53-69.

Blumer, H. 1951. "Social Movements", A. McClung Lee (Ed.), Principles of Sociology. New York: Barnes and Nobles, pp.199-220.

Castells, M. (2015). Networks of outrage and hope: Social movements in the Internet age. John Wiley \& Sons.

Coscione, M. (2015). Ciudades por el Comercio Justo: puentes entre Europa y América Latina. Otra Economía, 9(16), 18-28.

Dal Gobbo, A., and Forno, F., (2020). "Shopping for a Sustainable Future: The Promises of a Collectively Planned Consumption", in Forno F., and Weiner, R., (Ed.s), Sustainable Community Movement Organizations Solidarity Economies and Rhizomatic Practices. Routledge.

De Bernardi, P., Bertello, A., Venuti, F., \& Foscolo, E. (2020). How to avoid the tragedy of alternative food networks (AFNs)? The impact of social capital and transparency on AFN performance. British Food Journal, 122 No. 7, pp. 2171-2186. 
Diani, M., (2019). "Modes of Coordination in Political Consumerism", Boström, M., Micheletti, M., \& Oosterveer, P. J. M. (Ed.s), The Oxford Handbook of Political Consumerism, Oxford University Press.

Discetti, R., Anderson, M., \& Gardner, A. (2019). "Campaign spaces for sustainable development: a power analysis of the Fairtrade Town campaign in the UK". Practical Action Publishing.

Earl, J., \& Kimport, K. (2011). Digitally Enabled Social Change: Activism in the Internet Age. Cambridge, Massachusetts; London, England: The MIT Press.

Eden, S. (2017). Blurring the boundaries: Prosumption, circularity and online sustainable consumption through Freecycle. Journal of Consumer Culture, 17(2), 265-285.

European Commission, (n.d.) Ethical and Fair Trade City Award, https://www.trade-cityaward.eu/ (Accessed 15 May 2020)

Fairtrade Foundation. (2002). "Fairtrade Town Action Guide Update". Fairtrade Foundation Official Website. https://www.fairtrade.org.uk/Download.ashx?id=\%7B8F6B2BDB-F41E480D-8354-EA2E319C2244\%7D (Accessed 9 May 2020)

Fairtrade Foundation. (2018). "Annual Report and Financial Statements." https://www.fairtrade.org.uk/ /media/FairtradeUK/Media\%20Centre/News/2018/Fairtrade_F oundation_Annual_Report_2017.pdf (accessed 9 May 2020).

Forno, F., \& Graziano, P. R. (2014). "Sustainable community movement organisations". Journal of Consumer Culture, 14(2), pp. 139-157.

Forno, F., and Graziano P., (2020) Sustainable Community Movement Organizations (SCMOs): Reinvigorating Cooperatives and Mutualités via Post-Capitalistic Practices, Forno F., and Weiner, R., (Ed.s), Sustainable Community Movement Organizations Solidarity Economies and Rhizomatic Practices. Routledge.

FTAO, (2016) Localising the Sustainable Development Goals through Fair Trade. Fair Trade Advocacy Office Official Website. Available at http://localizingthesdgs.org/library/200/Localising-the-Sustainable-Development-GoalsSDGs-through-Fair-Trade-toolkit.pdf (accessed 29 July 2020).

Gabriel, Y., and Lang, T. (2006). The Unmanageable Consumer, SAGE Publications.

Gollnhofer, J. F., Weijo, H. A., \& Schouten, J. W. (2019). “Consumer movements and value regimes: Fighting food waste in Germany by building alternative object pathways". Journal of Consumer Research, 46(3), pp. 460-482.

Goodwin, J., Jasper J., and Polletta, F., "The return of the repressed: The fall and rise of emotions in social movement theory." Mobilization: An International Quarterly 5.1 (2000), pp. 65-83.

Gregson, N. and Ferdous, R. (2015) "Making space for ethical consumption in the South", Geoforum, 67 . pp. 244-255. 
Hilton, M. (2009). Prosperity for all: Consumer activism in an era of globalization. Cornell University Press.

Hoelscher, V., and Chatzidakis, A. (2020). "Ethical consumption communities across physical and digital spaces: an exploration of their complementary and synergistic affordances". Journal of Business Ethics.

IFTT (n.d), International Fair Trade Town Official Website, http://www.fairtradetowns.org. (Accessed 15 May 2020)

Jasper, J. M. (2011). "Emotions and social movements: Twenty years of theory and research". Annual review of sociology, 37, pp. 285-303.

Jubas, K. (2007). "Conceptual con/fusion in democratic societies: Understandings and limitations of consumer-citizenship". Journal of Consumer Culture, 7(2), pp. 231-254.

King, B. G., \& Pearce, N. A. (2010). "The contentiousness of markets: Politics, social movements, and institutional change in markets". Annual review of sociology, 36, pp. 249-267.

Kozinets, R., (2010). Netnography: Doing ethnographic research online. London: Sage.

Kozinets, R., (2020) Netnography. The Essential Guide to Qualitative Social Media Research, London: Sage.

Kozinets, R. V., Dolbec, P. Y., and Earley, A. (2014). "Netnographic analysis: Understanding culture through social media data", Flick U. (Ed.), The SAGE handbook of qualitative data analysis, London: Sage, pp. 262-276.

Kozinets, R. V., \& Handelman, J. M. (2004). "Adversaries of consumption: Consumer movements, activism, and ideology". Journal of consumer research, 31(3), pp. 691-704.

Kozinets, R. V., Hemetsberger, A., and Schau, H. J. (2008). “The wisdom of consumer crowds: Collective innovation in the age of networked marketing". Journal of Macromarketing, 28(4), pp. 339-354.

Kriesi, H. (1996). "The organizational structure of new social movements in a political context". Comparative perspectives on social movements, McAdam, D., McCarthy, J., and Zald M. N., (Ed.s), Cambidge, UK: Cambridge University press, pp. 152-184.

Kurth, L., Glasbergen, P. (2017) Serving a heterogeneous Muslim identity? Private governance arrangements of halal food in the Netherlands. Agric Hum Values 34, 103-118

Laamanen, M., Wahlen, S., \& Campana, M. (2015). "Mobilising collaborative consumption lifestyles: A comparative frame analysis of time banking”. International Journal of Consumer Studies, 39(5), 459-467.

Lamb, H. 2008. Fighting the Banana Wars and other Fairtrade battles. London: Random House. 
Lee, M., Ramus, T., \& Vaccaro, A. (2018). "From protest to product: Strategic frame brokerage in a commercial social movement organization". Academy of Management Journal, 61(6), pp. 2130-2158.

Low, W., \& Davenport, E. (2007). "To boldly go... exploring ethical spaces to re-politicise ethical consumption and fair trade". Journal of Consumer Behaviour, 6(5), pp. 336-348.

Malpass, A., Cloke, P., Barnett, C., and Clarke, N. 2007. "Fairtrade urbanism? The politics of place beyond place in the Bristol Fairtrade City Campaign”. International Journal of Urban and Regional Research 31(3), pp. 633-645.

Matzembacher, D. E., \& Meira, F. B. (2019). Sustainability as business strategy in community supported agriculture. British Food Journal, Vol. 121 No. 2, pp. 616-632

Micheletti, M., \& Stolle, D. (2008). "Fashioning social justice through political consumerism, capitalism, and the internet”. Cultural studies, 22(5), pp. 749-769.

Moraes, C., Szmigin, I., and Carrigan, M. (2010). "Living production-engaged alternatives: An examination of new consumption communities". Consumption, Markets and Culture, 13(3), pp. 273-298.

Morris, A. D., and Staggenborg, S. (2004). "Leadership in social movements", A. Snow, S. A. Soule, and H. Kriesi (Ed.s), The Blackwell companion to social movements, Oxford: Blackwell Publishing, pp. 171-196.

Muniz, A. M., \& O'guinn, T. C. (2001). "Brand community". Journal of consumer research, 27(4), pp. 412-432.

Närvänen, E., Koivisto, P., \& Kuusela, H. (2019). Managing consumption communities. Journal of Strategic Marketing, 27(5), 388-404.

Peattie, K., and Samuel, A. (2018). "Fairtrade Towns as unconventional networks of ethical activism”. Journal of Business Ethics, 153(1), pp. 265-282.

Potts, J. (2014). Forward, J. Potts, M. Lynch, A. Wilkings, G. Huppe, M. Cunningham, \& V. Voora (Ed.s), The state of sustainability initiatives review. Winnipeg/London: International Institute for Sustainable Development (IISD)/International Institute for Environment and Development (IIED).

Sage, C. (2014). "The transition movement and food sovereignty: From local resilience to global engagement in food system transformation". Journal of Consumer Culture, 14(2), pp. 254-275.

Sage, C. (2015), "Food and sustainable development: how should we feed the world?", Redclift, M. and Springett, D. (Ed.s), Routledge International Handbook of Sustainable Development, Routledge, Abingdon, pp. 264-278.

Samuel, A., Peattie, K. and Doherty, B., (2018). "Expanding the boundaries of brand communities: the case of Fairtrade Towns". European Journal of Marketing, 52(3/4), pp. 758782. 
Scaraboto, D., \& Fischer, E. (2013). "Frustrated fatshionistas: An institutional theory perspective on consumer quests for greater choice in mainstream markets". Journal of Consumer Research, 39(6), pp. 1234-1257.

Signori, S., and Forno, F. (2019). "Consumer groups as grassroots social innovation niches". British Food Journal, Vol. 121(3), pp. 803-814

Shawki, N. (2015). "The local fair trade movement: Understanding global discourses and local activism". New Political Science, 37(3), pp. 401-423.

Thompson, C. J., \& Coskuner-Balli, G. (2007). "Countervailing market responses to corporate co-optation and the ideological recruitment of consumption communities". Journal of Consumer Research, 34(2), pp. 135-152.

Tröster, R., \& Hiete, M. (2018). Success of voluntary sustainability certification schemes-A comprehensive review. Journal of Cleaner Production, 196, pp. 1034-1043.

Weijo, H. A., Martin, D. M., \& Arnould, E. J. (2018). "Consumer movements and collective creativity: The case of restaurant day". Journal of Consumer Research, 45(2), pp. 251-274.

Winkel, T., Núñez-Carrasco, L., Cruz, P.J. et al. (2020) Mobilising common biocultural heritage for the socioeconomic inclusion of small farmers: panarchy of two case studies on quinoa in Chile and Bolivia. Agric Hum Values 37, 433-447

Witzling, L., Shaw, B. R., Strader, C., Sedlak, C., \& Jones, E. (2020). The role of community: CSA member retention. British Food Journal, Vol. 122 No. 7, pp. 2289-2302. 